\title{
DiAlogiCAl MEDIATION AS AN INSTRUMENT TO PROMOTE HEALTH AND SOCIAL COHESION: RESULTS AND DIRECTIONS
}

\author{
Gian Piero Turchi \& Michele Romanelli
}

\begin{abstract}
One of the main challenges in Europe is to focus attention on public policies capable of promoting and maintaining social cohesion. We can see how the interaction between different cultural systems can radicalize the differences. Since those differences are assumed to characterize and identify elements of the specific social groups, they can cause conflicts in the community. This paper aims to describe the elements that allow the implementation of mediation in public policies. An operating model for both emergency use and in anticipation of conflict will be proposed for all the levels at which conflict itself may be generated or has developed: this model will be called "Dialogical Mediation" (Turchi \& Gherardini, 2014). This model operates on the interested parties not only in a direct way, but also through all the "voices" that may be involved in repercussions that the conflict may generate (the whole community as a consequence). This is when mediation can be offered as an instrument of public policy, for the management of dialogical interaction between the "migrant community" and the "hosting community", anticipating conflicts and sustaining interactions as a "single community".
\end{abstract}

KEYWORDS

Community; dialogical interaction; dialogical mediation; health; social cohesion

\section{A MEDIAÇÃo DIALÓGICA COMO INSTRUMENTO PARA PROMOVER A SAÚDE E COESÃO SOCIAIS: RESULTADOS E DIREÇÕES}

\begin{abstract}
RESUMO
Um dos principais desafios na Europa é focar a atenção nas políticas públicas capazes de promover e manter a coesão social. Podemos ver como a interação entre diferentes sistemas culturais pode erradicar as diferenças. Uma vez que essas diferenças são assumidas como a caracterização e a identificação dos elementos de grupos sociais específicos, elas também podem causar conflitos na comunidade. Este artigo visa descrever os elementos que permitem a implementação da mediação nas políticas sociais. Será proposto um modelo operacional, tanto para usar em situações de emergência, como de antecipação de conflitos, em todos os níveis nos quais o conflito possa, por si, ser gerado ou desenvolvido: este modelo será denominado "Mediação dialógica" (Turchi \& Gherardini, 2014). Este modelo trabalha com as partes interessadas não só de forma direta, mas também através de todas as "vozes" que possam estar envolvidas nas repercussões que o conflito possa gerar (e, como consequência, com toda a comunidade). É aqui que a mediação pode ser oferecida como um instrumento de política pública para a gestão da interação dialógica entre a "comunidade imigrante" e a "comunidade de acolhimento", antecipando os conflitos e apoiando uma interação como "comunidade única".
\end{abstract}




\section{INTRODUCTION}

In the following contribution we seek to describe the elements that make possible the use of mediation as an instrument available not only for the legal system, but for public policy as well. This contribution focuses in particular on managing migration flows.

After describing scenarios resulting from migration flows, a study of the regulations at the European level will be analysed to underline a series of critical aspects (of an operative nature) referring to mediation. Such argumentative passage, will allow to reach the proposal for a general theory of the mediation and also will introduce the operative system of the Dialogical Mediation (Turchi \& Gherardini, 2014).

This tool, being consistent with the epistemic status of the intervention area itself (conflict or controversy), is offered as an elective instrument for the management and promotion of the health of the territory on which it is employed, thus offering possible lines of intervention, both in anticipation of conflict and in an emergency. The final part of the contribution will be centred on mediation guidelines for social policy.

\section{NEW SCENARIOS, A CONTEXT OF INTERVENTION AND OPERATIVE RESPONSIBILITY}

The starting point of the argument is to put the recent migration flows into a historical and cultural framework and to consider, through time, prolonged movements of substantial numbers of individuals from one country to another, as a result of sociocultural situations of various types. These flows (also from one region to another or from different cities) have always characterized the history of our species.

To find a possible definition of migratory flow, we will consider the recommendations of the United Nations regarding statistics of international migration: "international migration is understood as the process of transfer of a citizen from a country of habitual residence to another country for a period of at least 12 months"'.

Migratory flows have always existed in the history of humankind, due to various factors. Though they do not make up the totality of cases, many of these factors are economic, forcing individuals to move from where there is less work, or where work is paid less, to places where there is more demand or work is better paid.

The Mediterranean area has always been a territory of people in movement. Taking advantage of coastal navigation, they transformed their commercial ventures either into stable settlements like the Phoenicians, or imposed their own forms of civilization and culture, such as the Byzantines, the Arabs, the Normans (Canale Cama, Casanova \& Delli Quadri, 2009). Today the European scenario, in the face of the conflicts in Mediterranean Africa, is an area of displacements of young people fleeing from their region and directed to Europe, crossing the door of access that is Italy.

Migratory flows have historically characterized the human community: the fact that groups move because of very different socio-cultural structures, transiting or staying in a territory, makes them interact with other people, thus generating scenarios that could go from contexts of peace to contexts of war, with all the intermediate variations. If the

\footnotetext{
' Retrieved from www.un.org
} 
focus of attention is maintained on the generative power of transiting and staying, the procedural nature of migration flows is clear. That is, as a process, they construct and generate always new and different socio-cultural structures (consequently we are in a diachronic and non-synchronic dimension).

This means that instead of studies and interventions on the presumed (and fallacious) causes of migratory flows, we should focus on the operative possibilities of managing "what" the migratory flows generate - or anticipating how much can be generated - considering both the social background of origin and reception.

We propose this focus in order to carry out actions aimed at activating an advanced management that can have repercussions for the territory in terms of both economic and community health. The focus of the intervention needs to be placed on the modalities of management of the socio-institutional and interactive structures that are modified as a result of migratory flows.

From this moment on, we are going to consider those contexts that require "new" operational proposals, not relegated to chance, but rather related to a cognitive apparatus that allows the monitoring of forms of management that are being employed. Such proposals must consider what is being generated and constructed at the moment in which groups of people pass over a certain territory (for more or less long periods) or settle within a certain community in a (more or less) permanent way.

Based on these considerations, we see "new" scenarios (which, as described above, are not new in terms of the processes that characterize them) for which the instrument of mediation can and should take over an operational responsibility with respect to the community.

From this moment, to define the field of application for mediation in such contexts, the notions "welcoming community" and "migrant community" will be used. By "welcoming community" we consider the community that, inhabiting the same territory, has generated the rules of social life proper to that territory. By "migrant community", however, we refer to someone who, inserting themselves into a community whose rules of social life have been defined (that is the welcoming community), has not been involved in the generation of said rules (Turchi, Fumagalli \& Paita, 2010).

Therefore, if the welcoming community, to manage the critical aspects that "naturally" arise in a community, can generate (case by case) modalities that in the course of time become tacit or explicit rules and conventions of administration of the social fabric, this does not happen for the migrant community. In this scenario the conflict, although it has not yet been declared between the parties, can be anticipated, as if the conflict were in a germinal phase, in a state of inertia, and then is suddenly manifested.

In other words, the critical aspect here is that people construct reality in different ways that change so that different historical and cultural structures are created, which, by common sense, concern cores of content such as traditions, dresses, and cultural differences. It might happen that, when such cultural systems interact, the differences are exacerbated and accentuated to a greater extent when the construction process is not shared. Thus, the dichotomy "welcoming community" and "migrant community" is 
useful in order to distinguish the two parties, but it is not appropriate, since they share the same territory, for which they are both responsible.

What happens instead - as in the example just presented - is that migration management policies move into action as soon as they conceive the migratory flows as a problem which are designed to defend against the dangers and not to manage a community. As a result, punitive or repressive measures are taken in order to control the problem, the fundamentalism that such a problem gives rise to, and the destructive force of its effects. Such management policies, then, create a contradiction: on one front the welcoming communities are described as assaulted, threatened, invaded in thousands of ways and on the other front the "invaders" are described as fleeing from misery and hunger, people transferred into completely different conditions of life and, now, also threatened with physical aggression.

Furthermore, in a community there are different demands based on the culture to which one belongs. In Italy, for example, during the last decades the migratory flows constructed migrant communities involving the coexistence of very different rules and social conventions. In many cases this has been managed by common sense according to a "work principle": migrants, considered by the host population as "those who contribute substantially to the economy", have enjoyed respect and consideration mainly for merits linked to employment (Turchi, Fumagalli \& Paita, 2010).

Regarding the previous examples, it is clear that migratory flows generate situations in which mediation can be used as an elective instrument. Therefore, professional figures must be competent in the analysis of processes, in anticipating the community structures, in moving towards solutions that meet the requirements of both the welcoming community and the migrant community, that is, of the community as a whole.

\section{THE STATE OF THE ART IN MEDIATION: NORMATIVE AND OPERATIVE POSSIBILITIES}

After the social changes generated by migratory flows in recent years, the countries of the European Union have paid particular attention to social cohesion. The differences between the various groups, in fact, have been radicalized or assumed as a unique point of reference to define and identify a specific group. This has provoked the need (for both the welcoming and the migrant community) to create a close-knit community.

During the "II Summit of the Council of Europe" in Strasbourg (held in October $1997^{2}$ ), the European Heads of State and of Government identified social cohesion as a strategy to face possible conflicts between citizens within the same community. To this end, the Council of Europe provided institutional legitimacy, in terms of a mandate, to propose and implement interventions promoting social cohesion. Specifically, social cohesion has been defined as "the capacity of a society to guarantee the well-being of all its members, minimizing disparities and avoiding polarization" and a cohesive society is defined as a "reciprocally solidary community of free individuals who pursue these common goals through democratic instruments". In addition, in 2001 the Council of Europe

\footnotetext{
${ }^{2}$ Available at http://www.coe.int/DefaultIT.asp
} 
launched the European Committee for Social Cohesion. This Strategy committed the 46 Acceding States to a work program that describes Social Cohesion in the following way:

it is a concept that includes values and principles, which indicates the condition of ensuring that all citizens, without any discrimination and from a position of equality, have access to fundamental social and economic rights. Social cohesion is a regulatory concept that constantly reminds us of the need to be attentive to the community and to be aware of every type of discrimination, inequality or exclusion.

On March 31, 2004, the Council of Ministers approved the updated version of the Council of Europe's Strategy for social cohesion, presenting the definition and identifying the future lines: social cohesion "is the capacity of a society to ensure well-being (welfare) of all its members, reducing differences and avoiding polarization. A society based on cohesion is a community of reciprocal support of free individuals pursuing common goals with democratic meanings" 3 .

The European regulation puts social cohesion at the base of European countries' social policy and it represents the "European social model". The operative mandate of mediation experts is also based on this definition of social cohesion. Consequently, the mediator is an expert who, at the disposal of the community, operates in order to create communities "reciprocally in solidarity and with free individuals that pursue these common goals through democratic instruments". With the knowledge that if community does not work for cohesion, then it results in conflicts, the mediator focuses on the "wellbeing of all its members, minimizing disparities and avoiding polarization".

What has been described up to this moment shows how mediation can have a strong attachment to relevant issues that involve the whole community, the management of community interactions, and, in more general terms, the health and well-being of its members.

\section{For A SCIENTIFIC Basis of Mediation: The General Theory of Mediation}

Historically theoretical-operative proposals for intervention in conflict have considered the object of the intervention in different ways, according to the theoretical approach. For example, conflict has been considered as the effect of communicative "dysfunctions" or of different parties' personal characteristics. As a consequence, the mediator presupposes the presence of specific causes of the conflict itself. All previous theoretical-operative proposals for intervention consider conflict as an empirical-factual entity, with an ontological statute.

According to the medical model, for instance, pneumonitis is a disease of the lungs and the respiratory system, in accordance with its epistemic status and with the empirical-factual data. Thus, it appears coherent as well as effective to adopt a mechanistic paradigm to restore the situation as it was before the intervention of the cause.

\footnotetext{
${ }^{3}$ Retrieved from http://www.coe.int/DefaultIT.asp
} 
Epistemological reflection (Turchi \& Gherardini, 2014) has revealed both epistemological and methodological errors in the study of mediation. We can say that researching cause-effect links is adequate when we can identify empirical-factual entities (the case of the medical model). Conflict, however, cannot refer to a factual object, but to a motus (a process) based on ordinary language used by the community of speakers. Its epistemological status is discursive production with its generative and configurative power (we mean here a "dialogical process"). The conflict, understood as a procedural (dialogical) and non-empirical element, derives from the use of certain modalities of interaction and is "in principle" always changing.

When using other discursive processes, the way of interacting changes and, as a result, the configuration of reality is modified, with pragmatic consequences; the configuration of reality is what the parties define as real. From this, we can say that a conflict can always be managed through interventions which are capable of modifying the process. Adopting this principle, the intervention does not look for the causes of the conflict, but to the ways the parties involved build the conflict situation. This principle, according to the research project carried forward by the team of the University of Padua and coordinated by Professor Gian Piero Turchi, lays the foundation of the General Theory of Mediation (Turchi, Tocci \& Romanelli, 2014), which offers the following analysis:

1. law is the most used tool to manage conflict interactions (and represents the basic modality of Society). This tool represents the set of written rules collected in Codes (the laws are codified rules). The way to manage interactions between parties, according to the application of Law, is to impose sanctions when the coded rule (the law) is violated;

2. another way to manage conflict interactions is Mediation, which represents the basic modality of Community. This tool is a set of language rules necessary to promote the construction of a unique rule common to the parties.

In the context of migratory flows, the role of a mediator is to promote interactions between the welcoming community and the migrant community and to help them to build the same reality. In a conflict, instead, the parties bring their own rules and realities and consider those as definitive and immediately recognizable to the other part.

Mediation is, then, an instrument which can be employed to interfere in interactive processes - which are dialogical processes - of delegation, employed by the community in relation to the system of services and institutions. In addition, mediation can share responsibility within the citizenship to manage the community itself, and - finally - it can anticipate a conflict even when this is not declared. This can allow us to interfere with the delegation processes toward issues that belong to community, that is when the responsibility is attributed exclusively to the administrations and services for finding solutions. It such cases the results may frequently be unsatisfactory for the citizenship, because the solutions in such cases are "imposed" and generated from "outside". 


\section{DiALOGICAL MEDIATION}

The operative praxis of dialogical mediation aims to change the discursive configurations of conflict. The intervention seeks to transform the exclusive realities of the parties involved into a third, shared reality, and it does not aim to demonstrate or determine anything (Turchi et al., 2010). Consequently, the elective instrument of mediation is able to pose the question which makes it possible to generate "other" discursive realities and to move away from the discursive reality named "conflict". The dialogical mediator creates and uses rhetorical-argumentative stratagems that allow them to generate a configuration of reality that is different from the discursive productions of the conflict parties.

In addition, if the operation of dialogical mediation is considered as able to anticipate that a conflict can occur, the mediator can use stratagems to guide the parties to share a unique reality that does not belong exclusively to any. As inhabitants of the same territory, the parties will thus have the same responsibility.

What emerges in the community (emergency) is already managed before it happens. Here, then, the anticipation of social structures that do not promote social inclusion, for example, results in interventions that aim to promote citizenship as an instrument of conciliation. Such a project seeks to give to the citizen a central role and makes it possible to deal precisely with those critical aspects that can cause communities to fragment.

\section{MEDIATION IN A COMMUNITY SETTING ACCORDING TO THE DIALOGICAL MODEL: THE Chiampo Valley PRoject}

The community mediation project "From conflict to neighbourhood mediation. Mediation as a resource for inclusion and access to housing" in the territory of Chiampo Valley (from September 2008 to December 2010) was a pilot experience. This project was proposed as experimentation, so that the outcome could be transferable to other contexts, territories and countries characterized by the same requirement.

The Chiampo Valley is a territory which as a result of the presence of a strong tannery industry has been characterised in recent years by a significant influx of migrants (equal to almost $40 \%$ of the population). The community mediation project was consequently implemented to face a series of critical developments due to the crisis of the productive sector: the increase of layoffs of migrants, the increase in requests from both Italian and foreign families for financial support, the management of school classes composed of students of various nationalities and languages (Turchi et al., 2010). Before the mediation project, the structure of the community had been guaranteed by what we called in the first paragraph above the "logic of work" (that is, the configuration of the migrant as a work force). But when the above critical developments appeared, the local administrators and the experts of the University of Padova anticipated that there would be conflict if they did not promote social cohesion. Furthermore, the conflict would be more serious because of the interactions of many different needs and demands. Here, then, the project worked on a not yet manifested conflict. 
The community mediation goal is "the promotion of citizenship as a shared responsibility" so that, as a consequence, each individual takes their place in the community and contributes to its development. The adoption of the dialogical model allows mediators to operate on a processual level, going beyond the merely legal issues of citizenship.

One of the strategies carried out to reach the goal of the project was the constitution of a team of mediators in the territory, with a seven-day and 24 hour operating centre collecting signals from citizens and developing a role of surveillance of the territory. To build a unique reality within the community, at the beginning of the project the team of the University of Padova trained citizens to be non-professional mediators and involved them in interventions with the professional mediators. This strategy allowed the promotion of citizenship responsibility also after the end of the project. Another strategy that promoted responsibility for the community was the constitution of a control room, a group with the role of looking for critical aspects to be managed and choosing the strategies to be carried out.

The results showed that the discursive productions collected at the beginning of the project were different from those ones met with at the end. A first, the populations did not contemplate that there was a possibility to manage the life of the community and they delegated solutions to the institutions. At the end, they created a structure of community responsibility. In addition, the results showed that social cohesion increased the perception of security. Finally, the project offered an evaluation of the effectiveness of the complete intervention and presented a cost-benefit analysis in order to evaluate the impact of the project itself on the community, both in terms of benefits obtained and of costs that would have been sustained had the conflict situations emerged. The cost-benefit analysis made it clear that the intervention was able to intercept conflict situations, so that from anticipating a conflict, the mediation project provided a strong economic saving from what otherwise would have been social costs.

\section{FROM CONFLICT TO COMMUNITY HEALTH: PATHS TO THE PROMOTION OF COMMUNITY HEALTH THROUGH MEDIATION}

After the description, on a general level, of a model that can manage migration flows, we can consider the definition of social cohesion that the European Union provides to carry out intervention programs. The definition focuses on "the capacity of a society to guarantee the well-being of all its members" 4 . Although this definition allows us to intervene at many levels, the construct of well-being it contains remains undefined.

It is necessary to define what we consider "well-being", as otherwise, taking for granted that its definition is known, we will not be able to observe its pragmatic repercussions and, as a consequence, the intervention can become invalid. For this reason, in the dialogical model "well-being" is substituted by health. Health is defined as: the set of discursive productions that promote a management of what is generated within the

\footnotetext{
4 Informations retrived from the Council of Europe Action Plan for Social Cohesion, "New Strategy and Council of Europe Action Plan for Social Cohesion" approved by the Committee of Ministers of the Council of Europe on 7 July 2010.
} 
community, through the use of anticipation and prefiguration processes of future scenarios that, although not yet available, are possible. The promotion of such a structure is exactly what mediation should be able to do.

Saying that mediation is an instrument to promote community health means that it can be used before conflict shows its pragmatic effects and, at the same time, that such an instrument operates so that a community, seen as responsible for its own health, can realize processes that lead to an increase in social cohesion. Mediation thus works with objectives that concern the promotion of community health. Mediation, together with other social services, is able to promote community health when specific instruments are defined and delimited, so that it does not overlap with the interventions that other services make but works within a network. The promotion of community health is an added value that mediation can create and manage effectively in order to develop synergies between services and attain a goal which cuts across all services whose target is the promotion of community health. After the argumentative route of this article, this last part is dedicated to the operative paths open to us which promote mediation as an instrument to promote health. They are:

- the adoption of an epistemic reference adequate to the object of the intervention, that is, conflict or controversy;

- the explicit reference to operational factors aimed at guaranteeing the effectiveness of the interventions in addition to the efficiency of the mediation service;

- the formation of professionals expert in mediation processes. Available to the community, these professionals work as sensitive cells of the territory, anticipating conflicts and then prefiguring possible future scenarios;

- the reference to the general objectives of the mediation service, that consider the health of the territory, security and social cohesion as products of the dialogue of all the actors;

- the adoption of forms of intervention that include the evaluation of their efficacy and the analysis of the pertinence of the interventions to their social context.

\section{REFERENCES}

Canale Cama, F., Casanova, D. \& Delli Quadri, R. M. (2009). Storia del Mediterraneo moderno e contemporaneo. Napoli: Guida Editori.

Turchi, G. P., Fumagalli, R. \& Paita, M. (2010). La promozione della cittadinanza come responsabilità condivisa. L'esperienza pilota di mediazione civica sul territorio della Valle del Chiampo. Padova: Upsel Domeneghini.

Turchi G. P. \& Gherardini V. (2014). La mediazione dialogica. Fondazione scientifica, metodo e prassi in ambito penale, civile e commerciale, familiare e di comunità. Milan: Franco Angeli.

Turchi, G. P., Tocci, M. \& Romanelli M. (2014). Libro bianco per la promozione dell"efficienza nell'Ammistrazione della Guistizia - Proposte in materia di risoluzione stragiudiziale dei conflitti e delle controversie. Padova: Cleup. 


\section{BIOGRAPHICAL NOTES}

Gian Piero Turchi is Professor of Clinical Psychology and Psychology of Cultural Differences at the University of Padua and director of the Postgraduate Course "Mediation as an operative method within the family, criminal, community, civil and commercial contexts". $\mathrm{He}$ is also President of the World Mediation Forum and author of many publications such as: "Valutare e misurare l'impatto biografico di un evento dannoso: lo strumento M.I.B" (2018); Minori e giustizia. La mediazione come strumento efficace ed efficiente per un ruolo attivo del minore nella comunità (2016); Libro bianco per la promozione dell"efficienza nell'Ammistrazione della Guistizia - proposte in materia di risoluzione stragiudiziale dei conflitti e delle controversie (2014); Flussi migratori, comunità e coesione sociale. Nuove sfide per la mediazione (2013).

Member of the Strategic Committee of the European CreE.A Project "Creation d'un Espace européen de la mèdiation for social inclusion" (2017 - in progress), he collaborates, as a consultant, with the Direction of Alternative Methods for Conflict Resolution (D.I.M.A.R.C) of the Ministry of Justice of Córdoba, Argentina.

ORCID: 0000000221545339

Email: gianpiero.turchi@unipd.it, gianpiero.turchi@gmail.com

Address: Dipartimento di Psicologia dello Sviluppo e della Socializzazione - DPSS Universidade de Padova, Via Venezia 8, 35131 Padova

Michele Romanelli is psychologist, mediator and teacher of the postgraduate course "Mediation as an operative method within the family, criminal, community, civil and commercial contexts". Author of publications such as: "Valutare e misurare l'impatto biografico di un evento dannoso: lo strumento M.I.B" (2018); Libro bianco per la promozione dell'efficienza nell'Ammistrazione della Guistizia - proposte in materia di risoluzione stragiudiziale dei conflitti e delle controversie (2014); Flussi migratori, comunità e coesione sociale. Nuove sfide per la mediazione (2013).

Member of the Strategic Committee of the European CreE.A Project "Creation d'un Espace européen de la mèdiation for social inclusion" (2017 - in progress).

ORCID: 0000-0002-5634-1117

E-mail: info@micheleromanelli.it

Adress: Dipartimento di Psicologia dello Sviluppo e della Socializzazione - DPSS

Universidade de Padova, Via Venezia 8, 35131 Padova

* Submitted: $20 / 07 / 2018$

* Accepted: $30 / 10 / 2018$ 